\title{
Managing Diversity in Nigeria: Competing Logics of Workplace Diversity
}

\begin{abstract}
Purpose: The literature on equality, diversity and inclusion in organizational and societal contexts has grown in leaps and bounds over the last two decades or so. Our understanding of these phenomena in a global context is however limited, as attention has mostly been paid to the United States and other Western countries. This chapter aims to address this gap by exploring workplace diversity in Nigeria, an under-researched context, characterized by high diversity and low inclusion. Our goal is to understand the factors that shape diversity management operating in such a challenging context, and to analyze the problems and prospects of building a highly diverse and inclusive environment.
\end{abstract}

Design/Methodology/Approach: Using a case study approach, the chapter analyzes four dimensions of equality and diversity (ethnic, religious, age and HIV/AIDS) across four organizations.

Findings: This exploratory study highlights the challenges of building a diverse and inclusive workplace in a weak institutional environment. We identify competing logics of managing diversity in Nigeria: institutionalizing ethnic representation vs. building a meritocracy (ethnic); maintaining religious neutrality vs. promoting religious freedom (religion); keeping the elder tradition vs. harnessing the power of youth (age); and managing safety and reputation vs. providing employment security (HIV/AIDS).

Originality/Value: This study sheds light on the importance of underlying thoughts on the effectiveness of diversity policies, and argues that managers and organizations need to know how to balance competing logics and manage paradox effectively. It accentuates the importance of the national institutional environment in shaping diversity practices, and provides insights for practitioners and policymakers.

\section{Keywords}

Workplace Diversity and Inclusion; Affirmative Action; Horizontal Inequalities; Ethnic Representation; Managing Paradox; Nigeria 


\section{Introduction}

As diversity and inclusion have become increasingly important in organizations and societies around the world, a burgeoning academic literature has emerged in this area. However, the literature has been dominated by research conducted in Western contexts, largely due to the emergence of the field in countries such as the United States of America. As the field develops, it has become important to understand how organizations manage diversity and inclusion in nonWestern countries, as well as the impact of different national contexts on diversity and human capital practices (Klarsfeld et al., 2014). This chapter explores workplace diversity in one of such under-researched countries, Nigeria.

Nigeria provides an interesting and useful context to explore equality, diversity and inclusion policy and practice. First, the country is characterized by unusually high levels of diversities, and is ranked among the five most diverse populations in the world (SHRM, 2009). Its 186 million people belong to three major ethnic groups and 250-400 different ethno-linguistic groups, with an almost equal number of Muslims and Christians; it has one of the world's youngest populations (a median age of 17.9), and with over 3 million people living with HIV, one of the highest prevalent rates in the world (Adeleye et al., 2014). Interestingly, Nigeria ranks poorly on several dimensions of inclusion, including social and government inclusion (SHRM, 2009). Third, its national antidiscrimination legal framework is weak, which provides organizations with sufficient managerial autonomy on diversity-related issues (Adeleye et al., 2012). Our aim is to understand how this somewhat unique context of high diversity, low inclusion and weak institutional environment impacts on diversity and inclusion policy and practice.

The rest of this chapter is organized into five sections. In the next section, we discuss the institutional and organizational context of equality and diversity management in Nigeria, focusing on four important dimensions: ethnic, religious, age and HIV/AIDS. This helps to understand the idiosyncrasies of the Nigerian context, and draws attention to the importance of the national institutional context on diversity and inclusion practices. We then provide a brief description of the case study approach used for this exploratory study. This is followed by an in-depth analysis of the competing logics of workplace diversity management in Nigeria we identified in this study: institutionalizing ethnic representation vs building a meritocracy (ethnic); maintaining religious 
neutrality vs promoting religious freedom (religion); keeping the elder tradition vs harnessing the power of youth (age); and managing safety and reputation vs providing employment security (HIV/AIDS). The penultimate section focuses on the implications of our findings for diversity and inclusion policy and practice, and the chapter concludes with a discussion of fruitful avenues for future research.

\title{
The Institutional and Organizational Context of Equality and Diversity Management in Nigeria
}

\author{
The weak institutional environment in Nigeria presents both opportunities and challenges \\ for managing diversity in organizations. On the one hand, organizations often fail to take \\ ownership for managing differences as they are not held accountable by government or \\ regulations, relegating diversity issues to the background. On the other hand, the liberal \\ and essentially voluntaristic approach of the diversity management concept is perceived as \\ less controversial, and may be more appealing to organizations... The reality in most \\ Nigerian organizations is that diversity management is yet to emerge.
}

Adeleye et al. (2014: 211)

Equality, diversity and inclusion have historically been problematic and controversial in Nigerian society. In 1999, an important step was made to deal with these issues, with a constitutional clause expressly prohibiting discrimination on the basis of community, ethnicity, place of origin, gender, religion and political opinion. In recent years, attempts have also been made to introduce legislations that specifically address different dimensions of diversity: age, gender, HIV/AIDS status, disability and sexual orientation (see, Adeleye et al., 2014). Most attention has however been paid to ethnic and religious diversity, which have been the most problematic areas for several decades. The national legal framework mainly covers ethnic diversity, using strict affirmative action quotas based on state of origin in public and political institutions; however, the legal framework is somewhat weak (SHRM, 2009). 
Generally, the diversity management concept has low maturity in Nigeria, as the emphasis on managing differences has narrowly focused on legal and moral factors, the so-called “discrimination-and-fairness” approach (Thomas and Ely, 1996; Adeleye et al., 2014). The socalled "business case for diversity", which is increasingly popular in West, and emphasizes the economic benefits of managing differences strategically (Klarsfeld et al., 2012), is not yet widely embraced. Further, the legal framework and institutional environment for equality, diversity and inclusion in Nigeria can be described as weak. Not surprisingly, Nigeria ranked $45^{\text {th }}$ out of 47 countries in the global diversity readiness index prepared by the Society for Human Resources Management, with a score of 31.3 out of 100 (SHRM, 2009). It actually received top ranking for being one of the top five most diverse countries, but high levels of exclusion and a weak legal framework drove down the country's diversity readiness. Nigeria ranked poorly on social and government inclusion, due to persisting ethnic and religious conflicts, underrepresentation of females in politics and higher education, and discrimination and victimization against gays/lesbians (SHRM 2009).

In such an environment characterized by high diversity and low inclusion, national diversity policy matters (Healy and Oikelome, 2007). Our goal in this section is to briefly highlight how the national institutional context and societal expectations for managing differences in business and society impact on four important dimensions of diversity in Nigeria: ethnic/cultural, religious, age and HIV/AIDS status.

\section{Ethnic Diversity}

Nigeria comprises of three "territorially separated and politically polarized ethnic groups" and another 250-400 ethno-linguistic groups (Sowell, 2004: 108). The three major ethnic groups account for nearly $60 \%$ of the country's population: the Hausa/Fulani in the northern region (29\% of the population), the Yoruba of the southwest region (21\%), and Igbo of the southeast region (18\%). Several hundred minority ethnic groups are scattered around the country, the largest of which is the Ijaw of the south-south region (10\% of the country population) (CIA World Factbook, 2013). The high level of ethnic diversity is further complicated by the intersection of ethnic and religion identities. The southern regions are predominantly Christian, with the exception of the 
southwest which has large followers of Christianity, Islam and indigenous African religions; Islam is widely practiced among the Hausa-Fulani in the northern regions, while many minority ethnic groups in the region practise Christianity.

Ethnic and religious identity have played a huge role in national politics since the colonial era, with aggressive ethnicity leading to recurring conflicts and riots across the country. Economic, educational and social horizontal inequalities exist across the ethnic groups and regions (Fenske and Zurimendi, 2017), and further exacerbates inter-group tensions and rivalry (Mustapha, 2009). As Mamman and Baydoun (2009: 194) succinctly put it: "many Nigerians owe their allegiance first and foremost to their ethnic/religious group than to an entity called Nigeria”. It is therefore not surprising that ethnic nepotism and favouritism are rife in organizations (Adisa et al., 2017).

Successive Nigerian governments have sought to foster a spirit of 'unity in diversity' over the decades, introducing a federal system of government, as well as quotas and zoning systems (Abdulraheem, 2011). One of the most consequential of these measures is the 'Federal Character Principle', which was enshrined in the 1999 constitution (ODI, 2006: 3):

The composition of the Government of the Federation or any of its agencies and the conduct of its affairs shall be carried out in such a manner as to reflect the Federal Character of Nigeria and the need to promote national unity, and also to command national loyalty, thereby ensuring that there shall be no predominance of persons from a few states or from a few ethnic or other sectional groups in that government or any of its agencies.

The Federal Character Commission (FCC) is charged with implementing and enforcing the federal character principle. The wide variation in educational attainment across states and regions has however made it difficult to enforce equity in the distribution of public posts among the federating units, and spurred debates on the unintended consequences of using strict quotas to institutionalize ethnic representation (Mustapha, 2009). Besides concerns about the usefulness of the approach to promoting cultural diversity, the FCC focuses narrowly on federal-level institutions, leaving out other levels of government and the private sector. Firms generally take advantage of this weak 
institutional environment, and beyond cookie-cutter non-discrimination statements, there is limited evidence of a systematic approach to managing cultural diversity (Adeleye et al., 2014).

\section{Religious Diversity}

Nigeria is a highly religious nation, with an almost equal number of Muslims and Christians, and a small number practising African traditional religions. The intersection of religious and ethnic identities, and the long history of inter-group tensions makes these very sensitive issues in the social and political arena. Such is the level of sensitivity that then President Olusegun Obasanjo decided in the last census in 2006 to not collect data on religion and ethnicity.

Religion permeates all aspects of life in Nigeria. A survey conducted by the Pew Research Centre (2006) on the importance of nationality, religion, ethnicity and Africa showed that an overwhelming majority of Nigerians see religion as central to their lives (see Table 1). This is more pronounced among Muslims, with over 90 per cent saying religion is most import in their lives; it is somewhat surprising that 0 per cent of those surveyed identified their ethnic identity as being important, although this could be explained by the deep intersection of ethnic and religious, especially in northern Nigeria.

\section{< Insert Table 1 Here >}

Perhaps unsurprisingly, religion features prominently in the political realm, and has contributed to inter-group conflicts and riots over the decades (Dowd, 2016). Some have argued that the root of these persisting conflicts was the amalgamation of the predominantly Muslim northern Nigeria protectorate and the heavily Christian southern Nigeria protectorate by the British in 1914 (Ochonu, 2014). The tensions reached a boiling point in 1999 when twelve northern states with majority Sunni populations chose to adopt sharia law adoption; many Christian communities were agitated, feared persecution and restriction of their freedom, and protested vehemently, culminating in bloody clashes (Ochonu, 2014). These tensions in society are, naturally, expected to spill into the workplace. And while the constitution prohibits discrimination on grounds of religion, the federal character principle does not cover religion per se, but the 36 federating states and six 
geopolitical zones. The intersection of religious and ethnic/state of origin identities means that the latter are often used as proxies for the former.

\section{Age Diversity}

Nigerian cultures tend to be hierarchical and gerontocracy runs deep in the country (Adeleye et al., 2014). Traditionally, it is believed that wisdom comes with age, so older people are well respected and treated with reverence. While these longstanding traditions may have served a well in the past, it can pose serious challenges in an era with a huge youth population (Nigeria's median age is 17.9, compared with South Africa's 25.3, India's 26.5, China's 35.9, the USA's 37.1, and Japan's 45.4; CIA World Factbook, 2013). One of the obvious challenges is the context of the workplace is age discrimination in the form of "age floors", where people are required to have attained a certain age before they can advance into senior positions or certain public offices; in the case of the latter, this is usually codified into law through age of candidacy requirements (typically between 30 and 40 years), or in other cases through custom or unwritten policies (Adeleye et al., 2014).

In what appears to be the most credible challenge to the status quo, the Not Too Young To Run (NTYTR) organization has been running a campaign to reduce the legal age of candidacy and inspiring young people to run for public office. Interestingly, the movement has now gone global, with the campaign now coordinated by the Office of the UN Secretary-General's Envoy on Youth, in partnership with the Inter-Parliamentary Union, European Youth Forum, UNDP, UN Human Rights Commission, and Youth Initiative for Advocacy, Growth and Advancement (YIAGA) (NTYTR, 2018). In Nigeria, the group's message appears to have gained traction, as they have pressured legislators and the presidency to pass a new law in May 2018 that reduces the legal age of candidacy by $5-10$ years.

Age discrimination also manifests in the form of 'age ceilings', where applicants to entry-level graduate programmes are required to not be above a specific age (usually 24 - 26 years), or

preference for "young and dynamic executives" below a particular age (Adeleye, 2009: 210). These cases of rampant discrimination exist in spite of a constitutional clause that prohibits age 
discrimination. There have been attempts to pass a legislation to prohibit age discrimination in organizations and to empower the Federal Character Commission to enforce regulations and penalties, but these have not been successful.

\section{Inequality and Exclusion Due to HIV/AIDS Status}

HIV/AIDS has a devastating impact on individuals, organizations and communities in Nigeria. The country had 3.2 million people living with HIV in 2016, the second highest HIV burden in the world. Many people living with HIV are not aware of their status due to limited access to testing, and only about 30 per cent have access to antiretroviral treatment, resulting in a high number of AIDS-related deaths (UNAIDS, 2018). There have been coordinated efforts at subnational, national and international levels to combat the disease, with prevalence rates coming down from the 5 per cent level in 2003, to under 3 per cent (Avert, 2017). In addition to fighting the disease, people living with HIV/AIDS have to battle against stigmatization and discrimination in employment, with many organizations having mandatory HIV/AIDS testing as part of preemployment screening (FMLP, 2013). A 2012 study by the Global Network of People Living With HIV found that over a quarter of Nigerian respondents were unable to secure employment after their HIV status was known, the highest among the countries surveyed (GNP Plus, 2012).

To address the issue of workplace discrimination, the Federal Ministry of Labour and Productivity, with the support of the International Labour Organization formulated a national workplace policy on HIV and AIDS with the objective of eliminating discrimination and stigmatization in the workplace and protecting the rights of people living with HIV and AIDS (FMLP, 2013). Further progress was made with the passing of the HIV/AIDS Anti-Discrimination Act 2014, which makes it illegal to discriminate against someone based on their real or perceived HIV status. The new legislation prohibits organizations from requiring people to take an HIV test as a precondition for employment or access to services.

\section{Research Design and Approach}

The current study is part of a larger, multi-year investigation into how organizations in Nigeria manage differences, what paradigms and strategies they adopt, and the influence of strategic, organizational and national institutional context in shaping their approaches to managing equality, 
diversity and inclusion. Given that diversity management in the Nigerian context is underresearched, with literature just emerging in recent years, we chose a qualitative research design. Such an approach is advantageous as it helps to gain an understanding of underlying reasons, opinions, and motivations of phenomena being investigated (Creswell, 2007). We use the case study method, which especially lends itself to exploratory research (Yin, 2014). The critical case sampling approach is adopted as it helps to gather rich information from cases that dramatically highlight topical issues, in addition to being effective when there are logistical and resources constraints; while this approach does not lend itself to broader generalizations, it is possible to make "logical generalizations" from the evidence produced (Patton, 1990). We selected cases that represent different organization types (public, private and nonprofit), firm sizes (large, mediumsized and small), as well as different key sectors of the Nigerian economy: oil and gas, financial services and healthcare. The specific cases were chosen following a systematic search of information from prior studies, published sources and consultations with subject matter experts who were familiar with diversity and talent management issues in the Nigerian context.

The study focused on four important dimensions of diversity and inclusion that were identified in prior research: ethnicity, religion, age and HIV/AIDS; we therefore chose four case study organizations that had faced diversity challenges that can be considered typical of each of these areas: Nigerian National Petroleum Corporation (NNPC), AMB Bank, Not Too Young To Run (NTYTR) and Imperial Medical Centre (IMC). NNPC is a large state-owned enterprise involved in oil exploration and production, gas development, petrochemical distribution, engineering, and refinery services; it is an employer of choice, and a focal point of debates on the federal character principle/ ethnic diversity. AMB Bank (a disguised name, given the sensitivity of religious issues and Islamic banking in Nigeria) is a middle-tier retail bank with nationwide operations; the bank is seeking to expand its footprint in the predominantly Islamic northern region of Nigeria. NTYTR is a relatively new nonprofit organization aiming to reduce age discrimination and inspiring young people to seek public office. IMC is a private primary healthcare provider that was the subject of the first lawsuit that successfully challenged employment termination and discrimination based on HIV status. These are all high-profile organizations whose diversity management challenges are quite representative of those faced by organizations operating in Nigeria. 
We relied extensively on secondary data sources from organizations (company reports, company websites, and annual reports), research publications (government reports and statistics, reports by multilateral institutions such as the International Labour Organization), diversity surveys and reports (for example, the Society for Human Resource Management/ Economist Intelligence Unit Global Diversity and Inclusion survey report). Thematic analysis was adopted for the analysis of case study data. The data were analyzed using themes, codes and keywords based on an extensive survey of the literature. One of the most important issues we examined was whether diversity and inclusion practices are motivated by the traditional legal or moral case for diversity (affirmative action), or whether they are embracing a strategic, business-driven approach (affirming diversity) (Thomas, 1990). In conducting our analysis, considerable attention was paid to context sensitivity, to ensure that our findings are placed in the right social, historical, temporal, as well as strategic and institutional context.

\section{Competing Logics of Workplace Diversity in Nigeria}

It is now accepted wisdom in both academic and professional circles that building a diverse workforce leads to increased sales revenues, access to larger markets and greater profits, and higher levels of creativity and innovation (FT, 2014; Slater et al., 2008; Thomas, 1990). As with many other management practices (or fads, as some sceptics might point out), the rhetoric does not (always) match the reality in organizations. Which raises several pertinent questions: If indeed strategic diversity management offered all these immense benefits, why would organizations in highly diverse societies not embrace it? Why do organizations in highly diverse environments fail to build an inclusive workplace? Why would social inclusion and government inclusion be low in diverse communities? Put differently, what are the barriers and challenges to successful implementation of strategic diversity and inclusion? How can diversity policy makers and practitioners overcome these barriers?

To address these topical questions, we posit that a deep understanding of the context in which organizations are embedded is required, not least the social, historical and institutional context. Nigeria provides a fertile ground to undertake such an investigation, with its high levels of diversity, 
low inclusion, weak institutional environment and a low rate of adoption of strategic diversity initiatives (SHRM, 2009; Adeleye et al., 2014). Our research objective, therefore, is to understand the underlying thought processes and prevailing paradigms on managing differences in organizations, going beyond the rhetoric of strategic diversity management. Rather than focus on just organizations' statements and information packs on this subject, our critical approach necessitates an extensive analysis of alternative viewpoints of other important stakeholders.

Our findings reveal competing logics and viewpoints in all our four focal areas of diversity: institutionalizing ethnic representation vs. building a meritocracy (ethnic); maintaining religious neutrality vs. promoting religious freedom (religion); keeping the elder tradition vs. harnessing the power of youth (age); and managing safety and reputation vs. providing employment security (HIV/AIDS). Table 2 provides a summary of the key issues and challenges arising from these competing logics. In the rest of this section, we provide case study evidence that reveals the dynamics of these tensions in organizations and society, and explain the consequences for the effective management of diversity in the Nigerian context.

\section{< Insert Table 2 Here >}

\section{Competing Logics in Managing Ethnic Diversity: Institutionalizing Ethnic Representation vs. Building a Meritocracy}

Affirmative action and the Federal Character Commission are unavoidable necessities forced on Nigerian national life by the cleavages and inequalities that have scarred the nation.

Mustapha (2009: 574)

The federal character principle as practiced in Nigeria diverts emphasis from merit (based on hard work and achievement) to sharing privileges and benefits accruable from representative bureaucracy, it thus limits effectiveness in public bureaucracy and ultimately national development. 
Gberevbie and Ibietan (2013: 58)

The Nigerian National Petroleum Corporation (NNPC) is a large state-owned enterprise involved in oil exploration and production, gas development, petrochemical distribution, engineering, and refinery services. It is the holding company for the federal government's interests in oil and gas industry, Nigeria's economic mainstay. Most of the exploration and production takes place in the oil-rich but impoverished Niger Delta, in the south-south geopolitical zone comprising of several ethnic minority groups. This has created a lot of tension as indigenes of the oil producing states want more control, ownership and revenue share from the economic activities generated in their area. Given the dominant role NNPC plays in the Nigerian economy, it is regarded as an employer of choice by many people across the nation, and a focal point in the "talent war" between the country's ethnic groups.

One major source of friction is the dominance of people from the three major ethnic groups (nearly $70 \%$ of the country's population) in the corporation and industry, even though their states and geo-political zones are not major oil producers. The bigger challenge seems to be allegations of ethnic favouritism against the sitting president (who usually oversees the corporation) or other members of the ruling class and elites. In an ongoing case, for example, a senior lawyer, Mr Olisa Agbakoba, filed a lawsuit to challenge the non-inclusion of the south-east geopolitical zone in the nine-member board of the corporation; he asked the court to declare the "lopsided" appointments unconstitutional, null and void (The Cable, 2017). The basis of this challenge was the federal character principle, and the strict quotas imposed by the Federal Character Commission for such national appointments. This requires that each of the 36 federating states must constitute at least $2.5 \%$ and not more than $3 \%$ of the total positions available at national offices; where there were two senior positions, one person should be from the northern regions and the other from the south; and when there at least six positions, each of the six geopolitical zones must be represented (Mustapha, 2009). The problem in this case was that the president (who is from the north) had not included anyone from the south-east zone, whereas some other zones had more than one appointee. Such allegations of ethnic discrimination, favouritism and nepotism are common in Nigeria (George et al., 2017; Adisa et al., 2017), and to some extent, underscore the importance of 
the federal character principle, which seeks to ensure that no federating unit is marginalized in national appointments.

At lower levels in the organization, especially for engineering roles and professional positions (for example, accountants and lawyers), NNPC faced a different, more serious challenge. Since this required hiring only people who met exacting (international) standards, the emphasis was on individual merit. The affirmative action quotas were inappropriate for recruitment and promotions here because of the uneven distribution of highly qualified talent across the federating states and zones.

NNPC once sought to use federal character in the employment of oil-sector engineers. Despite repeated efforts, northern candidates with the requisite skills were not available. The NNPC was then given special dispensation to recruit from anywhere in the country.

Mustapha (2009: 570)

The huge economic and educational inequalities between the north and south, as well as between the six geopolitical zones, posed a serious challenge to the implementation of the federal character principle.

Beyond these practical challenges of implementing the federal character principle, there appears to be a groundswell of opposition to using strict quotas and formulas in recruitment and promotion at the philosophical level (Gberevbie and Ibietan, 2013; George et al., 2017). The core of this argument is that positions should be filled solely on merit, and that quotas are ultimately counterproductive as they institutionalize mediocrity in the workplace, and even play a role in the decision of highly skilled professionals to migrate overseas (Healy and Oikelome, 2007).

Thus, in the case of NNPC, even if there was a sufficient supply of talent across the federating units in the country, for an organization operating in a globally competitive industry, hiring and retaining the best talent - irrespective of their state of origin - would perhaps be the strategic thing to do. Furthermore, the firm operated in a competitive market with talent shortages, and its employees 
where often required to work with highly-qualified professionals from their multinational joint venture partners, bringing the issue of promoting a meritocracy to the fore. This case epitomizes the challenges of striking a balance between upholding merit on the one hand, and ensuring equitable and fair representation in culturally divided societies on the other. As we will argue in the rest of this section, building a sustainable organization in such environments requires paying serious attention to the benefits and risks of these competing logics.

\section{Competing Logics in Managing Religious Diversity: \\ Maintaining Religious Neutrality vs. Promoting Religious Freedom}

The Central Bank of Nigeria...has expended huge sums of government funds to train its staff both locally and abroad, as well as engage consultants to promote the take-off of Islamic banking in Nigeria. Since the current CBN Governor assumed office, $90 \%$ of those employed by this federal establishment are Muslims from the core-North.

Christian Association of Nigeria (2011: 30), in Sampson (2014: 415)

The opposition to Islamic banking is uncalled for and uninformed... The country is made up of Muslims, Christians, traditional religionists and others, we cannot therefore run away from things Islamic because we have Muslims among us. They have a right if they want a non-interest banking that is advocated by their religion. And I don't see how that impacts on the rights of any other person or endangers either the economy or the society. In the first place, roughly 70 per cent of Nigerians are unbanked.

Cliff Mbagwu, in Ndujihe (2011: 13)

AMB Bank (disguised name, given the sensitivities about religion and Islamic banking in Nigeria) is a retail bank that offers conventional financial services nationwide. A middle-tier player in a highly competitive industry that is heavily concentrated in Lagos State and the southern parts of the country, the bank has struggled to grow and gain market share. With the approval of Islamic banking in Nigeria, the bank sought to become a major player in this uncontested market space 
and expand its footprints in the north, where it is a relatively marginal player. The bank was aware and cautious of the controversies generated by the introduction of Islamic banking and efforts to delegitimize it (as the quotes at the head of the section illustrate). Among senior executives of the bank, there was a split on the proposed entry into the Islamic banking space, roughly along personal religious lines.

For executives that identified as Christians, it was paramount for the bank to maintain its religious neutrality and not confuse the market about its corporate brand. This was a big concern as the only other major institution offering Islamic banking services was a fully-fledged Islamic bank, and the move by the bank could be perceived as a conversion to an Islamic bank, rather than inclusion of Islamic banking products in its portfolio of programmes. Beyond the brand perception issue, some of them reasoned along with the Christian Association of Nigeria that Islamic banking was a further attempt to Islamize the country; the initiative was being pushed by the then Central Bank Governor, Sanusi Lamido Sanusi, who was an Islamic scholar and grandson of the former Emir of Kano, a powerful religious leader in northern Nigeria. This was also happening a few years after Sharia law was introduced in twelve northern states, resulting in heightened tensions and violence. There were also concerns that Islamic banking violates the constitutional principle of nondiscrimination on religious grounds, and that public funds should not be used to promote it (Sampson, 2014). For these reasons, several executives maintained the bank should stay out of the controversy, as it risked provoking a backlash and alienating its core customer base in the predominantly Christian south.

On the other hand, several executives argued that this was essentially a religious freedom matter. That the Western-style banking services offered by most players in the sector were in violation of Islamic law, which forbids charging interest on financing, and stipulates sharing of profits or losses with the borrower to minimize unnecessary speculation and spread risk (Reuters, 2017). This was considered a contributing factor to the extremely high percentage of the population that is unbanked (70\%) (Sampson 2014), with the size of the Islamic banking market estimated to be 80 million (Reuters, 2017). Several AMB executives pushed for the bank to move fast to seize this market opportunity, as a full-fledged Islamic bank, as well as two mainstream banks had commenced operations. 
These competing viewpoints elongated the decision-making process, and created frictions in the management team. Even though the business case was apparent, the fear of getting embroiled in controversy in a religiously polarized environment, and the uncertainties about how existing (Christian) customers would react have resulted in analysis paralysis.

\section{Competing Logics in Managing Age Diversity:}

\section{Keeping the Elder Tradition vs. Harnessing the Power of Youth}

Respect for age is a predominant cultural value in Nigeria. Through early socialization, people are taught to respect older people... Old age is often equated with wisdom with older people perceived as more experienced, and hence wiser. When they make decisions, a younger person is expected to oblige without any challenge.

Ovadje and Ankomah (2001: 183)

One of the issues that have recently dominated national discourse is the need for a generational power shift to youths in Nigeria come 2019 or beyond. Nigerian youths in the vanguard of this campaign believed they have been short changed in the past and are demanding a generation shift in who governs Nigeria as political reparation for past youth marginalization in political leadership.

Babalobi (2018: 1)

Gerontocracy is deeply rooted in many Nigerian cultures and often manifests itself in government and public sector organizations and institutions, as the quotes above illustrate. While age discrimination affects both the young and the old, most of the attention in recent times has been on the former. The accepted wisdom that older people should take charge of leadership and decision-making, the "elder tradition", is increasingly challenged - socially, politically and legally. On the legal front, Nigeria is among the countries that still have a relatively high age of candidacy: 30 for federal and state legislative positions, 35 for state governors and federal senators, and 40 for 
president; outside these constitutional provisions, government and public sector organizations and institutions often impose lengthy work experience requirements (Adeleye et al., 2014).

There is now a groundswell of opposition to this gerontocratic system, led by the Not Too Young To Run (NTYTR) movement. NTYTR was established in 2016 with the goal of eliminating the legal age of candidacy and inspiring young people to run for public office (NTYTR, 2018). The movement builds on similar past initiatives aimed at empowering the youth, in a country with a widening "youth bulge" - more than half the population is less than 30 years old (United Nations, 2015). This demographic advantage, and perhaps the fact that the private sector now has many young successful executives and leaders, has brought the issue of eliminating age barriers in government and public sector organizations and institutions to the fore. Elected officials have appeared sympathetic to NTYTR's cause, in part because it fits well with government's narrative of gaining a demographic dividend and accelerating economic development by harnessing the power and potential of the youth (Omoju and Abraham, 2014). Besides, there have been many cases around the world where youth restiveness became politically "disruptive", and a pattern towards youthful democratic leaders was discernible (The Economist, 2011).

NTYTR has received global attention and solidarity, and the movement is now spearheaded by the Office of the United Nations Secretary-General's Envoy on Youth, as well as the InterParliamentary Union, United Nations Development Programme (UNDP), United Nations Human Rights Commission, Youth Initiative for Advocacy, Growth and Advancement (YIAGA) and European Youth Forum (NTYTR, 2018). Their energized advocacy, including through digital platforms using the \#NotTooYoungToRun hashtag, appears somewhat successful as a relatively high number of young people have announced running for office in the 2019 general elections. The "Not Too Young To Run Bill”, which seeks a constitutional amendment to reduce the age of candidacy for elective offices by between 5 - 10 years, was signed into law by the president in May 2018. These modest achievements within a relatively short time illustrate that cultural values are not static, and that providing viable progressive alternatives can help to effect change in diversity policy discourses and practices.

\section{Competing Logics in Managing Inequality Due to HIV/AIDS Status:}




\section{Managing Safety and Reputation vs. Providing Employment Security}

Majority of the employers in the private and public sectors were of the opinion that a staff living with HIV and AIDS should not be invited to attend a social gathering of this organization involving other workers and visitors. This might be as a result of the unscientific beliefs, prejudices and wrong notions held about HIV and AIDS.

Dipeolu (2014: 4)

In 2012, a study found that up to 45\% of surveyed persons living with HIV lost their jobs in the previous year on account of their seropositive status, while 42\% had been denied a promotion. In my experience, people are still denied employment, forced to resign or retire.

Onyemelukwe (2017: 163)

There are over three million people living with HIV in Nigeria, many of them in the most economically productive stage of their lives. The country has the second highest HIV burden in the world, with 220,000 new infections and 160,000 AIDS-related deaths in 2016 (UNAIDS, 2018). Stigmatization on the basis of HIV status is rife in society and employers routinely discriminate against employees and job seekers, as the quotes above illustrate. On a positive note, there have been a number of success stories with new legal protections for people living with HIV at state and federal levels. One important event that changed the direction of the discourse on HIV/AIDS and employment (in 2012) was the Georgina Ahamefule vs. Imperial Medical Centre \& Dr. Alex Molokwu lawsuit.

Imperial Medical Centre (IMC), a private primary healthcare provider, had fired Ms. Ahamefule, an auxiliary nurse, after performing a HIV test on her without obtaining informed consent. The physician named in the lawsuit also failed to provide pre-and post-test counseling to the nurse after the diagnosis, and denied her medical care. This case is interesting because the discrimination was perpetrated by a by a healthcare provider (who perhaps was the best equipped person to handle such issues), and also because the claimant was even prevented by a judge from attending court 
proceedings on the grounds that she may pass on the disease to others in court (Adeleye et al., 2014). The stigmatization experienced by this employee is not uncommon in Nigerian workplaces, especially healthcare organizations. Partly due to concerns about disease control and prevention, as well as fears about negative reaction by patients, many healthcare providers believe that HIV positive staff should not be allowed to mingle with other staff and visitors (Dipeolu, 2014). The thinking here is that with the high level of public stigma associated with disease, retaining HIV positive staff could scare away other staff and customers, tarnish the reputation of the healthcare institution, and ultimately hurt their business interests.

The IMC lawsuit moved very slowly through the judicial system for well over a decade; in 2012, the court eventually ruled that Ms. Ahamefule's termination was unlawful and constituted a wrongful termination as the plaintiff posed no material risk to the employer; it also found the denial of counselling and treatment unlawful, and awarded her N7 million (then about $\$ 44,000$ ) (Onyemelukwe, 2017). This landmark judgement energized advocacy groups such as the Network of People Living with HIV and AIDS in Nigeria (NEPWHAN), and resulted in several states passing new laws. At the national level, the HIV and AIDS (Anti-Discrimination) Act, 2014 was eventually passed, prohibiting discrimination against people on the basis of HIV status and making it illegal for any employer, individual or organization to require a person to take an HIV test as a precondition for employment or access to any services. The legislation was especially lauded because it addressed the contentious issue of involuntary testing that had posed a serious threat to the employment security of millions of people who want to remain productive and contributing members to society. While these new legislative developments will not automatically eliminate the public stigmatization, for healthcare organizations it decisively means that employment security must be taken seriously. The positive side is that in high prevalence societies, adopting progressive HIV/AIDS policies can help enhance corporate reputation among stakeholders (ILO, 2008; Bakuwa and Mamman, 2012). 


\section{Implications for Diversity Policy and Practice}

This study has several important implications for diversity practitioners. First, that diversity and HR professionals need to step up their role in helping organizations balance the competing logics of diversity management. In an environment characterized by high levels of diversity, low levels of inclusion, and historically weak but evolving institutional arrangements, change is desirable and inevitable. Diversity and HR professionals have an opportunity (and perhaps an obligation) to put diversity and inclusion on the agenda, filling the leadership void in their organizations. As change agents, they can play a range of professional roles: radicals, liberal reformers, or tempered radicals (Kirton et al., 2007). In the Nigerian context, while they cannot afford to just aim for minor procedural changes (liberal reformers), they must resist the temptation to embrace overly ambitious transformative goals as this may alienate internal and external stakeholders and even provoke backlash and resistance (radicals). As we have argued in this chapter, balancing competing diversity logics is important. Hence, we recommend acting as tempered radicals with a dual identity, opposing the status quo as well as overly radical change.

Such a pragmatic approach requires a short- and long-term strategy, taking incremental steps towards transformational change and realizing the need to balance competing logics as well as the interests of disadvantaged groups with those of their organizations (Kirton et al., 2007). Balancing competing logics and learning tempered radicalism requires managing paradox. As Leslie, Ping Li and Zhao (2015) argue, professionals and organizations that manage paradox are better performers than those who do not, and can use this capability to overcome resistance to change. Paradoxical thinking helps to explore opportunities and advantages in the competing diversity logics, as well as reduce the inherent tensions. Further, diversity professionals should sensitize their organizations to a paradoxical lens, which will help them manage paradox and diversity better.

For policymakers, our study underscores the importance of the institutional context in shaping diversity discourses and practices. Diversity and inclusion issues have been relegated to the background in Nigeria because organizations, especially those in the private sector, are not held accountable by government. This liberal and voluntaristic approach needs to change. In the public sector, the government needs to reconsider the overreliance on strict affirmative action quotas, 
since they appear to be aggravating ethnic tensions, and develop a long term strategy that directly deals with the inequalities and conditions that made those policies necessary at all (Mustapha, 2009). Policymakers, like diversity professionals, need to effectively balance the competing logics we identified in this study. They will benefit from an evidence-based approach to policymaking. Such an approach requires evaluating the effectiveness of current diversity legislations and regulatory enforcements, identifying best practices for promoting diversity and inclusion in government and public sector organizations, and drawing lessons from other highly diverse and divided countries.

\section{Conclusion and Avenues for Future Research}

This study provides case study evidence on organizations operating in a dynamic environment, with ongoing changes in the business, legal and institutional landscape. Future studies can investigate how organizations in the emerging context have adapted to these changes, and whether and how these have changed diversity discourses and practices in Nigeria. Given that the study is exploratory and relied extensively on secondary data, more in-depth updates are needed to provide richer data and insights that can help unpack the underlying thought process of the diversity discourses in Nigeria; in particular, we need to understand the processes of how organizations and policy makers are able to successfully achieve and maintain balance between competing diversity logics. It would also be beneficial to unpack the philosophical underpinnings of diversity policies and practices, with special attention paid to reframing the so-called business case for diversity. Van Dijk et al. (2012), for instance, propose the values and virtues perspective in place of deontology and utilitarianism, the philosophical basis of equality and business case perspectives respectively. Future studies should help uncover if and how these philosophical perspectives play out in diversity discourses and practices in Nigeria. More importantly perhaps, there is a need for studies that incorporate traditional African philosophy like Ubuntu into the diversity discourse, providing a culturally grounded approach to tackle discrimination and promote tolerance, diversity and inclusion in organizations. 


\section{References}

Abdulraheem, I. (2011), "The meaning and interpretation of diversity in Nigeria: a critical review", International Journal of Business Policy and Economics, Vol.4 No.2, pp. 323-332.

Adeleye, I., Aja-Nwachukwu, F. and Fawehinmi, Y. (2012), "Managing diversity in Nigeria: the Chevron way”, Human Resource Management Journal, Vol.4 No.1, pp. 1-13.

Adeleye, I., Atewologun, D. and Matanmi, O. (2014), "Equality, diversity and inclusion in Nigeria: historical context and emerging issues”, in Klarsfeld, A., Booysen, L., Ng, E., Roper, I. and Tatli, A. (Eds.), Country Perspectives on Diversity and Equal Treatment, International Handbook on Diversity Management at Work (2nd edn.), Edward Elgar, Cheltenham and Northampton, pp. $195-216$.

Adisa, T., Osabutey, E. and Gbadamosi, G. (2017), "The challenges of employee resourcing: the perceptions of managers in Nigeria", Career Development International, Vol. 22 No.6, pp. 703 723.

Alalibo, A. (2010), "Age discrimination in Nigeria”, available at:

http://www.info/News/Pages/ItemPage.aspx?Item5396.

Avert (2017), "Global HIV and AIDS statistic", available at: https:/www.avert.org/global-hivandaids-statistics.

Babalobi, B. (2018), "Youths revolt against gerontocracy in Nigerian politics", available at: https://www.pmnewsnigeria.com/2018/04/20/youths-revolt-against-gerontocracy-in-nigerianpolitics/.

Bakuwa, R. and Mamman, A. (2012), "Factors hindering the adoption of HIV/AIDS workplace policies: evidence from private sector companies in Malawi", The International Journal of Human Resource Management, Vol.23 No.14, pp. 2917 - 2937. 
Christian Association of Nigeria (2011), "Press Statement by the Christian Association of Nigeria on Non-Interest (Islamic) Banking”, Daily Trust, 4 July, pp. 30.

CIA World Factbook (2013), "The World Factbook: median age”, available at: www.cia.gov/library/publications/the- world-factbook/fields/2177.html.

Creswell, J.W. (2007), Qualitative inquiry and research design: choosing among five approaches. (2nd edn.), Sage, Thousand Oaks, CA.

Dipeolu, I. O. (2014), "HIV and AIDS in workplace: the role of behaviour antecedents on behavioural intentions”, African Journal of Medical and Health Science, Vol. 43 No1, pp. 131140 .

Dowd, R. A. (2016), "Religious diversity and religious tolerance: lessons from Nigeria", Journal of Conflict Resolution, Vol. 60 No.4, pp. 617-644.

Federal Ministry of Labour and Productivity (2013), "National workplace policy on HIV and AIDS, availabl at:

http://www.labour.gov.ng/Doc/NATIONAL_WORKPLACE_POLICY_ON_HIV_AND_AIDS. pdf.

Fenske, J., and Zurimendi, I. (2017), “Oil and ethnic inequality in Nigeria”, Journal of Economic Growth, Vol.22 No. 4, pp. 397-420.

Financial Times (2014), "The evidence is growing - there really is a business case for diversity", Financial Times, 14 May, available at: https://www.ft.com/content/4f4b3c8e-d521-11e3-918700144 feabdc0.

Franck, R., and Rainer, I. (2012), "Does the leader's ethnicity matter? Ethnic favoritism, education, and health in sub-Saharan Africa”, American Political Science Review, Vol. 106 No. 2, pp. 294325. 
Gberevbie, D. and Ibietan, J. (2013), "Federal character principle and administrative effectiveness in the Nigerian public service: challenges and prospects for sustainable development, 1999-2012”, Journal of Sustainable Development in Africa, Vol. 15 No. 6, pp. 46-61.

George, O., Yusuff, K. M. and Cornelius, N. (2017), "The good, the bad, and the ugly in the melting pot: the challenges of Nigerianizing diversity management", Equality, Diversity and Inclusion: An InternationalJournal, Vol. 36 No.3, pp. 238 - 254.

GNP Plus (2012), "Evidence brief: stigma and discrimination at work - findings from the PLHIV Stigma Index”, Amsterdam: Global Network of People Living with HIV, available at: https://www.gnpplus.net/evidence-brief-on-stigma-and-discrimination-at-work-findings-from-theplhiv-stigma-index/

Healy, G. and Oikelome, F. (2007), “A global link between national diversity policies? The case of the migration of Nigerian physicians to the UK and USA”, International Journal of Human Resource Management, Vol. 8 No. 11, pp. 1917-33.

International Labour Organization. (2008), “Managing HIV/AIDS in the Workplace: Employers' Handbook for Action”, Geneva, ILO.

Kirton, G., Greene, A. and Dean, D. (2007), "British diversity professionals as change agents radicals, tempered radicals or liberal reformers?", International Journal of Human Resource Management, Vol. 18 No.11, pp.1979-1994.

Klarsfeld, A., Combs, G., Susaeta, L. and Belizón, M. (2012), "International perspectives on diversity and equal treatment policies and practices”, in Brewster, C. and Mayrhofer, W. (Eds), Handbook of Comparative Human Resource Management, Edward Elgar, Cheltenham, UK and Northampton, MA, pp. 393-415.

Klarsfeld, A., Booysen, L., Ng, E., Roper, I., \& Tatli, A. (2014), "Introduction: equality and diversity in14 countries - analysis and summary", in Klarsfeld, A., Booysen, L., Ng, E., Roper, 
I., Tatli, A., (ed.), (2014), International Handbook on Diversity Management at Work - Country Perspectives on Diversity and Equal Treatment, (2nd ed.). Cheltenham: Edward Elgar.

Leslie, J.B., Ping Li, P. and Zhao, S. (2015), Managing paradox: blending east and west philosophies to unlock its advantages and opportunities, Centre for Creative Leadership, Greensboro, NC.

Mamman, A. and Baydoun, N. (2009), "Managerial perspective on the impact of globalization in an African commercial bank: implications for strategy implementation”, International Journal of Organizational Analysis, Vol. 17 No. 3, pp. 184-201.

Mustapha, A. R. (2009), "Institutionalising ethnic representation: how effective is affirmative action in Nigeria?”, Journal of International Development, Vol. 21 No. 4, pp. 56-576.

Ndujihe, C. (2011), “Opposition to Islamic banking uninformed” Vanguard Newpapers, 9July, available at: https://www.vanguardngr.com/2011/07/opposition-to-islamic-banking-is-uninformedcliff-mbagwu/.

Not Too Young To Run (2018). "We believe that if you're old enough to vote, you're old enough to run for office!” About, available at: http://www.nottooyoungtorun.org/about/.

Ochonu, M. (2014), “The roots of Nigeria’s religious and ethnic conflict”, available at: https://www.pri.org/stories/2014-03-10/roots-nigerias-religious-and-ethnic-conflict.

Odita, A. O. and Egbule, S. (2015), "Workforce diversity and organisational effectiveness in Nigerian brewery Industry”, Developing Country Studies, Vol. 5 No. 8, pp. 79-85.

Omoju, O. and Abraham, T. (2014), "Youth bulge and demographic dividend in Nigeria", African Population Studies, Vol. 27 No.2, pp.352-360. 
Onyemelukwe, C. (2017), "Discrimination on the basis of HIV status: an analysis of recent developments in Nigerian law and jurisprudence”, International Journal of Discrimination and the Law, Vol. 17 No. 3, pp. 160-179.

Ovadje, F., and Ankomah, A. (2001), "Human resource management in Nigeria”, in Budhwar P. S. and Debrah, Y. (Eds.), Human Resource Management in Developing Countries, Routledge, London: pp. 174-189.

Overseas Development Institute (2006), “Affirmative Action: Nigeria”, available at: http://www.odi.org.uk/inter-regional_inequality.

Patton, M. (1990), Qualitative Evaluation and Research Methods, (2nd edn.), Sage, Newbury Park, CA.

Pew Research Centre (2006), "Spirit and power: a 10-country survey of Pentecostals”, available at: http://www.pewforum.org/2006/10/05/spirit-and-power/.

Reuters (2017), "Nigeria to offer liquidity support to boost Islamic banking, August 24, available at: https://www.reuters.com/article/nigeria-islamicfunds-cenbank/nigeria-to-offer-liquidity-support-toboost-islamic-banking-idUSL8N1LA5EX.

Sampson, I. T. (2014), "(De)legitimising I-banks: the controversy over Islamic banking in contemporary Nigeria”, Canadian Journal of African Studies / Revue canadienne des études africaines, Vol. 47 No. 3, pp. 405-426.

Sampson, I. T. (2012), "Religious violence in Nigeria: Causal diagnoses and strategic recommendations to the state and religious communities”, African Journal on Conflict Resolution, Vol. 12 No. 1, pp. 103 - 134 .

Slater, S., Weigand, R. and Zwirlein, T. (2008), "The Business Case for Commitment to Diversity", Business Horizons, Vol. 51, pp. 201-209. 
Society for Human Resource Management (2009), Global Diversity and Inclusion: Perceptions, Practices and Attitudes, SHRM, Alexandria, VA.

Sowell, T. (2004), Affirmative action around the world: an empirical study, New Haven, Yale University Press, CT.

The Cable (2017), “Agbakoba sues FG over 'lopsided' appointments at NNPC”, available at: https://www.thecable.ng/agbakoba-sues-fg-lopsided-board-appointment-nnpc.

The Economist (2011), "Gerontocracy: does the difference between the age of a country's people and its leader matter?”, 15 February, available at: https://www.economist.com/blogs/dailychart/2011/02/age_and_leadership.

Thomas, R. (1990), "From Affirmative Action to Affirming Diversity", Harvard Business Review, Vol. 69, pp.107-117.

Thomas, D. A. and Ely, R. J. (1996), "Making differences matter: a new paradigm for managing diversity", Harvard Business Review, Vol. 74, pp. 79-90.

United Nations (2015), "World Population Ageing”, available at: http://www.un.org/en/development/desa/population/publications/pdf/ageing/WPA2015_Report.pd f.

United Nations Programme on HIV and AIDS, (2018), "Nigeria”, UNAIDS, available at: http://www.unaids.org/en/regionscountries/countries/nigeria.

Van Dijk, H., Engen, M. and Paauwe, J. (2012), "Reframing the business case for diversity: a values and virtues perspective”, Journal of Business Ethics, Vol. 111 No. 1, pp. 73-84. 
Yin, R. K. (2014), Case Study Research: Design and Methods, (5th edn.), Sage, Los Angeles, CA. 